
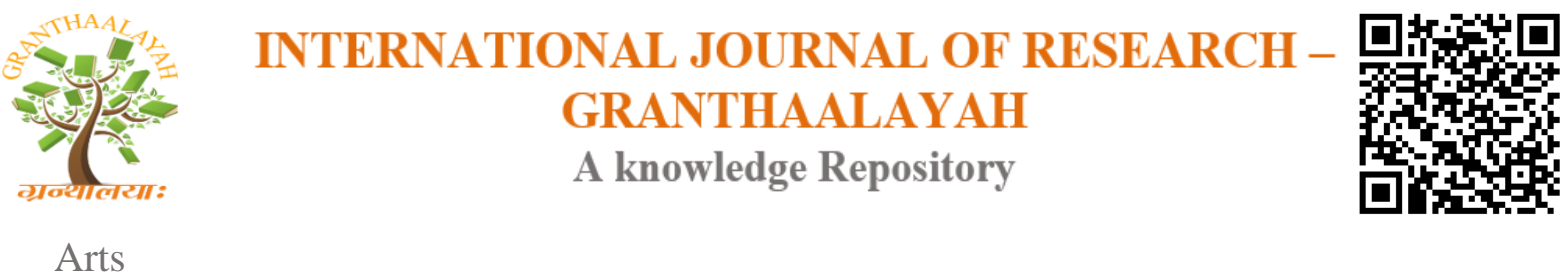

\title{
THE INFLUENCE OF ART MOTIF BATIK MEGA MENDUNG CIREBON TO FESYEN IN JAKARTA
}

\author{
Menul Teguh Riyanti ${ }^{1}$, Melisha Rouselyn ${ }^{* 1}$ \\ ${ }^{1} \mathrm{MPd}$, the Faculty of Art and Design of Trisakti University, West Jakarta, Indonesia
}

\begin{abstract}
Development of fashion and fashion is growing very rapidly. Indonesia's population of 242 million is a very large business opportunities in the field of fashion. This market share not only contested by foreign businessmen, as designers from France, Japan, Korea and even China. With increasing competition in the domestic fashion, then the local designers have to work hard to improve the competitiveness of both the face of the market share within and outside the country. Diverse effort is made to provide a reliable characteristic as an attraction by fashion designers in the country such as administering local elements in works such as weaving, batik, traditional motifs and others. One effort to give a traditional touch in the design of clothing as well as promoting one motif mega cloudy to improve the competitiveness of fashion in Indonesia as well as abroad, Melisha Rousellyn along with Menul Teguh Riyanti tried to apply the art of batik mega cloudy in the work of fashion. One effort to give a traditional touch in the design of clothing as well as promoting one motif mega cloudy cirebon in order to improve the competitiveness of fashion in Indonesia as well as abroad. Changes batik originally sacred to the development of contemporary batik into fashion. Batik is one of Indonesia's cultural products.
\end{abstract}

Keywords: Art Batik Mega Cloudy; Cirebon; Fashion.

Cite This Article: Menul Teguh Riyanti, and Melisha Rouselyn. (2018). "THE INFLUENCE OF ART MOTIF BATIK MEGA MENDUNG CIREBON TO FESYEN IN JAKARTA." International Journal of Research - Granthaalayah, 6(3), 105-125. https:// doi.org/10.29121/granthaalayah.v6.i3.2018.1504.

\section{Introduction}

\subsection{Background}

In the modern century and the era of globalization for society especially women function clothes not only to cover the body, but also for beauty for sipemakai. The demands of an increasingly advanced era of fashion and fashion development in Indonesia especially Jakarta very rapidly with talented young designers at the national and international levels. With a huge population of Indonesia that is 242 million open business opportunities in the field of fashion. This market share is not only contested by foreign entrepreneurs, such as designers from France, Japan, 
Korea and even China. With the increasingly fierce competition of fashion competition in the country, the local designers have to work hard to improve the competitiveness of both market share inside and outside the country. Various attempts were made to provide reliable features as a fashion attraction by domestic designers such as incorporating local elements in works such as weaving, batik, traditional patterns and others. Not a few designers in the country who have entered the ranks of international designers, call it Gea Sukasah, Ramli, Tech Saverio, Iwan Tirta and Hary Dharsono and others.

One effort to give a traditional touch in clothing design as well as promoting one of the mega cloudy batik motifs of Cirebon in order to improve fashion competitiveness in Indonesia as well as abroad. Batik changes originally sacred with the development of today's batik into fashion.

Batik is one of Indonesian cultural products. In its development, batik experienced the development of complexion, techniques and functions due to the passage of time or commonly called the development of the times and touches of various other cultures. Batik in wake with an artistic basic view that developed in accordance with the demands of the times.

The birth of batik marked with Indonesian art tradition, is a manifestation of integral values as a blend of complementary dualism "Dual Concept". Therefore, Indonesian traditional art is revealed in the form of decorative, symbolic, and dynamic decoration. The concept of artistic culture of Indonesia is very broad, not only the skin but also the content that combined to achieve balance and sustainability.

In the Indonesian tradition there is no artwork that is made solely for beauty, otherwise there is no wearing object (daily / ceremony / social / belief / religion) that origin can be used, it must be beautiful, not just satisfy the eyes, but also melt the rules moral, custom, taboo, religion, and so on, in addition to meaningful, as well as beautiful. (Primadi Tabrani, 1995)

Decorations in batik can be distinguished from ethnic groups, regions, even hamlets.

Archaeological finds are statues inside Ngerimbi temple near Jombang that depict Raden Wijaya, the first King of Majapahit (1294-1309) who wear Kawung decorative cloth (VanDer Hoop, 1949). Decorative on the fabric is made by painting techniques, prada, woven sungkit or batik. Batik Indonesia has a uniqueness of crafts, complexity, and subtlety of decoration due to cantingnya tread. The Potential of batik is big enough and widespread. The batik craftsmen await the helping hand of the designers and artists who will lift the batik into an attractive commodity in the eyes of the public and welcomed a glorious future in the fashion industry.

A brief history of batik, the function of batik use and how to wear it is also the technique of making it. With the aim that the younger generation know that both are great and beautiful works of art that must be maintained, loved and preserved. The users of batik mega cloudy grown a sense of love for the proud of batik wear for formal everyday fashion or informal.

Batik art is a traditional Javanese art that faces the threat of change in the era of globalization. Batik textile industry that was originally labor-based (labor intensive) turned into a capitalintensive mass industry (capital intensive). Especially in Jakarta as the capital and icon of Indonesia is the fashion center of all regions in Indonesia. Batik here is better known as the 
textile industry than a work of art, the process of manufacture is no longer using canting with individual hands but using textile printing machine, for mass production, from mass production it then made various kinds of clothing / apparel. Some designers homeland still many who use pure batik art / traditional batik mega cloudy. Batik mega cloudy initially only used by the upper middle class who really understand the fashion, every fashion designer fashion performances Indonesia always promote batik mega cloudy as one of the alternative clothing ready to wear very charming and unique in proklamirkan as fashion trends starting from 2007 until currently.

The purpose of batik motive mega cloudy in the design for formal clothing and party upscale, but over the times and fashion trends that are growing rapidly more and more fashion models of clothes from the formal penetrated into daywear and accessories, for men and women and even children. Art Batik Motif Mega Mendung not only used on upper middle class, but can be used by all circles of society.

1) Problem Restriction Based on the background of the problem, the main problem in the research The influence of the art of batik mega cloudy Cirebon motifs on fashion is limited in Jakarta that the motive was previously only on the tarekat in Cirebon is now a fashion trend, especially Jakarta as Indonesia fashion barometer in order to improve market competitiveness.

2) Problem Identification and Problem Formulation The market share of fashion is very wide open inside and outside the country, so to improve the competitiveness of domestic designers have to work hard to be able to create a specific and interesting work. One of the efforts is to apply the art of mega overcast motif Cirebon in fashion, but whether these efforts can improve competitiveness in the market both at home and abroad?

3) Research purposes. To know and analyze whether or not the influence of the art of batik mega cloudy Cirebon in fashion to improve the competitiveness of the market, and introduce the art of batik motif mega cloudy to the public in Jakarta.

\section{Literature Review}

Reviewing the purpose of people wearing clothes, it turns out that the purpose of each person is not necessarily the same. Some see it from the side of physical needs, while others see from the psychological side, it will certainly be different. While somewhere, people dress for reasons of physical need for nature, elsewhere people wear clothing not for the same reason. This is due to differences in customs, natural circumstances, customs and values prevailing in the community. In the book The Second Skin, mentioned the purpose of fashion in terms of various points of view as follows;

1) From the study of Anthropology; Anthropological studies enable us to conclude, for example, that using clothing to express modesty is a function that is determined by the culture, by instinctive in nature. People cover or decorate their bodies for, variety of reasons and modesty is only one. Other reasons include protection, the desire to be sexually attractive, and adornment. (Hom \& Gurel 1981: 3)

Anthropological studies have led to the conclusion that humans or a particular group of people dressed in the purpose of covering the body is a function determined by the 
culture one learns and not merely natural instincts. Another reason is to protect the body, adorn the body and the desire to appear sexually attractive.

2) From historical studies; Historians' methods make it possihle to interpret current clothing phenomena against the perspective of time. (Horn \& Gurel, 1981: 315) By the way,

Fashion phenomena can be interpreted over time by noting fluctuations in clothing over several periods, it is also possible to forecast the effects of social change on the motifs and styles of clothing.

3) In the context of psychology; Psychologists are concerned with how individual organisms respond to specific stirnuli (Horn \& Gurel, 1981: 3)

The text above can be interpreted: fashion is a stimulus and simultaneously as a response, received by humans differently.

4) From a sociological point of view, T'he links between the individual and the society as a whole is provided by the concept of role and status. In this respect, clothing is a symbol of the individual's role and status in soci, and it provides rewards of recognition, approval, and identification for the wearer. (Horn \& Gurel, 1981: 3)

The meaning of the text above is as follows; Clothing is concerned with the attitude and behavior of human beings, which is also a symbol of one's role and social status. It contains an appreciation of the recognition, justification and identification of the wearer. Culture and civilization are present because of the past. Clothing as a material object of culture and civilization is also started from the past and continues to grow until now. Relating to certain underlying reasons, the fashion function can be classified into four theories according to Horn \& Gurel is through the theory of modesty, immodesly theory, protection theory and decoration theory.

\subsection{Cultural Formation}

Humans as the highest creatures are able to create culture. One that humans form as homo creator, human creator, is society. Society continues to develop from its modest, narrow territory, to an advanced culture and vast territory. Followed by man himself as the creator of culture and its supporters, so that no culture seems to be $100 \%$ static (stagnant, stopped). Although the culture seems to be static, it is actually progressing slowly, so it appears in the humble culture of the village. In contrast to the culture of the city appears rapid progress in a short time, so that people call it a culture of advanced, dynamic culture. One of the important elements that make urban culture faster is the many challenges (challenges) that can be answered (response) by urban community.

In fact, humans are not the only factors that form the culture, there are several other factors as its formers. Including the following:

\section{The Natural Environment (Environmental)}

The natural environment is very influential on the culture of modest society, precisely because they are still as natural man (natural man) whose life is solely expect from nature. 


\section{Human Nature}

Although humans have the same posture, but are closely related to the environment, they are formed differently from one another. For example in the Minangkabau tribe whose men do not have the same rights as women (adat matriarch), has encouraged him to wander and most of them become merchants. In madura tribe with its barren nature causes them to be hard-tempered people. In contrast to the Javanese whose area was quite supportive of the environment and, moreover, with Hindu influences, it caused them to have a nrimo culture. The Batak and Ambon tribes that possess the beautiful nature and influence of the church make them famous singers.

\section{The Economy}

The people whose search for agriculture causes them to be more patient and nrimo by the natural upbringing, the newly planted crops patiently awaited him until the time of giving results, they are aware of the existence of such a law of nature and the life of hemar. While those who seek trade will be hard-earned asekares how quickly gain a profit (homo economicus), they take into account the profit-loss of an activity in his life, so it has a stingy nature.

\section{Education}

The natural environment, human nature, and economy tend to be a natural factor in the formation of human culture. While education tends to be a creation in creating something new. In a traditionally customary society, the younger generation continues to act like their ancestors, not even daring to change the fear of being tired of sinning. While the more advanced society prioritizes education as the ingredients.

Design is an art creativity created by someone with basic knowledge of art and beautiful taste (Sadjiman Ebdi Sanyoto, 2005: 1). According to Sri Widarwati (2000), design is a design or description of an object made based on the arrangement of lines, shapes, colors and textures. Arifah A Riyanto (2003: 1) argues that design is a rendition of something that can be manifested in real objects or human behavior, which can be felt, seen, heard and touched. From some opinions above can be concluded that the design is a design object or picture made based on the arrangement of lines, shapes, colors and textures that can be felt, seen, heard and touched and can be shown in a person's creativity.

\subsection{Elements and Design Principles}

Elements According to Sri Widarwati (2000: 7) the elements of fashion are everything that is used to construct a design. Codjijah, Wisri A. Mamdy (1982) argues that the element of design is anything that is used to create works of art that have suau form (rupa). Meanwhile, according to Prapti Karomah and Sicilia Sawitri (1986: 35) elements of the design elements are everything that is arranged to get the design. And according to Ernawati (2008: 202). Design elements are elements of the elements used to realize the design so that others can read the design. Based on the above description can be concluded that the element is everything that is used to create a design of art / design can be read or understood by others in this case is a fashion design.

Here are the elements of design:

1) The lines are the oldest elements used by humans in expressing feelings or emotions (Sri Widarwati1993: 7). Whereas according to Prapti Karomah and Sicilia Sawitri (1986: 350) 
the line is a set or set of dots drawn from point one other point, in accordance with the direction and purpose. Then according to Sadjiman Ebdi Sanyoto (2005: 7), the line can cover the deficiencies contained in the human body shape and serves to (a) limit the shape; (b) determine the model; (c) determine the silhouette; (d) determine direction. What is meant by line elements is the result of scratches with hard objects on the surface of natural objects (soil, sand, leaves, stems, trees and so on) and artificial objects (paper, walls, and so on) (Ernawati, 2008: 202).

Based on some opinions above can be deduced that the line is a collection of points that are combined in accordance with the direction and digoreskan on the surface of natural and artificial objects to express the feelings and emotions of a person.

According Widjiningsih (1982) Basically the line there are two kinds of straight lines and curved lines. Straight line impressed tension, certainty, stiffness and firmness. The curved lines are lithe, beautiful, feminine, and soft. False so that one example of the application of lines on the fashion design is the empire line located under the female breast. From the lines that are made always give its own impression or that is often called the nature / character of the line. The properties of the line according to Ernawati (2008: 202) are as follows: a) The nature of straight line Straight line has a rigid nature and gives the impression of solid, really really and hard, but with the direction of line nature can change like:

1) The straight upright line gives the impression of nobleness

2) The horizontal straight line gives the impression of calm

3) Straight / tilted straight lines are a combination of properties

4) Vertical and horizontal lines that have more vivid (dynamic) properties.

\subsection{Elements and Design Principles}

Elements According to Sri Widarwati (2000: 7) the elements of fashion are everything that is used to construct a design. Codjijah, Wisri A. Mamdy (1982) argues that the element of design is anything that is used to create works of art that have suau form (rupa). Meanwhile, according to Prapti Karomah and Sicilia Sawitri (1986: 35) elements of the design elements are everything that is arranged to get the design. And according to Ernawati (2008: 202). Design elements are elements of the elements used to realize the design so that others can read the design. Based on the above description can be concluded that the element is everything that is used to create a design of art / design can be read or understood by others in this case is a fashion design.

Here are the elements of design:

1) The lines are the oldest elements used by humans in expressing feelings or emotions (Sri Widarwati1993: 7) Whereas according to Prapti Karomah and Sicilia Sawitri (1986: 350) the line is a set or set of dots drawn from point one other point, in accordance with the direction and purpose. Then according to Sadjiman Ebdi Sanyoto (2005: 7), the line can cover the deficiencies contained in the human body shape and serves to (a) limit the shape; (b) determine the model; (c) determine the silhouette; (d) determine direction. What is meant by line elements is the result of scratches with hard objects on the surface of natural objects (soil, sand, leaves, stems, trees and so on) and artificial objects (paper, walls, and so on) (Ernawati, 2008: 202). 
Based on some opinions above can be deduced that the line is a collection of points that are combined in accordance with the direction and digoreskan on the surface of natural and artificial objects to express the feelings and emotions of a person.

According Widjiningsih (1982) Basically the line there are two kinds of straight lines and curved lines. Straight line impressed tension, certainty, stiffness and firmness. The curved lines are lithe, beautiful, feminine, and soft. False so that one example of the application of lines on the fashion design is the empire line located under the female breast. From the lines that are made always give its own impression or that is often called the nature / character of the line. The properties of the line according to Ernawati (2008: 202) are as follows: a) The nature of straight line Straight line has a rigid nature and gives the impression of solid, really really and hard, but with the direction of line nature can change like:

1) The straight upright line gives the impression of nobleness

2) The horizontal straight line gives the impression of calm

3) Straight / tilted straight lines are a combination of properties

4) Vertical and horizontal lines that have more vivid (dynamic) properties.

According to the above description it can be concluded that the design principle is a way to combine elements of design according to certain procedures so as to give a combination of effects / specific impact There are 6 principles of design that is

\section{Harmony (harmony)}

Harmony is a unity among the various elements though different but makes each part seem united (Sri Widarwati, 1993: 15). Meanwhile, according Widjiningsih (1982: 10) alignment is a principle in art that gives the impression of unity through the choice and arrangement of objects and ideas. The alignment can be realized in lines, shapes, colors and textures.

Then according to Ernawati (2008: 211) harmony is a design principle that gives the impression of unity through the selection and arrangement of objects or ideas for the existence of harmony and the impression of conformity between one part with another part in an object, or between one thing with another object combined. According to the above description of alignment is the unity of the element of a design through the arrangement of objects applied in lines, shapes, colors and textures. According to Sri Widarwati (1993), the aspects of the principles in harmony or harmony are as follows:

(a) Alignment in lines and shapes

(b) Alignment in texture

(c) Alignment in color

\section{Proportion}

The proportions are relationships with each other in a single arrangement (Widjiningsih, 1982: 13). Comparison is used to reveal more. In Fashion and Identity the work of Fashion theory from Fred Davis (1992) says that there is a significant relationship between fashion, culture and identity (Dewi Meyrasyawati, 2013: 101) According to Dewi Meyrasyawati Fashion and Identity (2013: 101) he quotes " we see fashion as a cultural phenomenon, then the clothing was none other than a meaningful practice that took place in everyday life, which helped shape the culture as a system of general meaning. Therefore, fashion is one of the containers for human beings to communicate, experience, explore, and produce social order "(Barthes, 1983: 3-5). In this 
discussion about fashion design, can be seen how fashion system construct cultural values. Cultural studies see the phenomenon of fashion as something that is constructed by the fashion system. Adolescents identify the culture they profess through how they dress. Referring to the theory of fashion system from Roland Barthes (1990), fashion is a sign system. The way we dress is a sign to show who we are and what our cultural values are. So the way of dressing is no longer seen as something neutral and something commonplace. Big or smaller and gives the impression of a relationship with each other that is clothing with the wearer (Sri Widarwati, 1993: 17). Proportion is the principle of the relationship between the design department as a whole (Sri Ardiati Kamil, 1986: 62). The proportion is the ratio of the parts to the other parts that are combined (Ernawati, 2008: 211).

Toffler's lifestyle means that every individual has a mark as his identity to distinguish it from other groups (Walker, 1989: 155). The lifestyle of a person or group of people, one of which relates to the way a person conducts his life, how one decides to choose and make choices. Toffler's argument is reinforced by Chaney's assumption that lifestyle is a picture of modern life or so-called modernity, meaning that those who live in modern society will use lifestyle devices to identify their actions as well as others.

Lifestyle is the pattern of action that distinguishes a group of people with other groups (Chaney, 1996: 4). Lifestyle is a part of everyday human life, and its function is to interact in various ways, where aka tone is likely to be unintelligible or unacceptable to those who live in a modern society. According to Chaney, the polapola of social life is sometimes characterized by the existence of culture. Some observers define culture as the totality of the lifestyles of a society that includes traditions, attitudes and norms that unite them into a society. As for his relationship with fashion or fashion, Walker in his book Design History of Design on styling and lifestyle styles, style and fashion, mentioned that fashion can refer to a variety of human attitudes, but more precisely refers to the enthusiasm of a person in certain fashion a fashion (style) and fashion are closely related to one's appearance or attitude, which of course must involve the factors of consumption, reception and taste (Walker 1987: 171), according to Russell ( 1992: 55), one of the most versatile elements for a design is color. Color can attract attention and help create a mood (mood). Depending on the appeal of a design work, colors can be used for the following reasons:

1) Color is a tool to get attention

2) Colors can highlight realistic elements realistically in color

3) Color has a psychological language that composes the work Design according to Reswick is "creative activity that brings renewal". In addition to the design also contained several things, among others: taste, instuisi, creativity, taste, self-esteem, privacy, values, norms of pride, kerahasisaan happy and so forth, all of which can not be measured mathematically. In the design itself required a concept known as the design concept, which includes design philosophy and considerations aimed at realizing the idea / design that is reality. This is called the conceptual design, namely:

1) Functions; functional meaning appropriate, functional design means appropriate design

2) Safe; safe means to protect people from harm, meaning that the design must be precisely to make quiet for the connoisseur of the design itself, janan until because the design makes it restless and uneasy 
3) Skilled; skilled means deft, agile, nimble, capable, and ingenious. In the world of skilled designs are often also understood understanding of mastery of engineering

4) Economical; the design requirements, especially those that are related to production are the economic considerations. Economics does not necessarily relate to price, but also information about efficient, effectiveness, and practical form of the end of a design.

5) Aesthetically; aesthetic is a personal medium that includes: character, character, attitude, belief, mood, depth, kematangandan personality. In the design work, aesthetic aspects are very important to note for the right form and harmonious

6) Attitude (ethical dimension); attitude is part of the depth of a work. A design that does not have the same attitude as a man hesitates.

\section{Research Methods}

Research method in this writing using descriptive method. The use of the approach adapted to the purpose of research is to describe.

According Sugiyono descriptive research is a study conducted tethadap variable and independent without comparison or connect with other variables. Then according to Suharsimi Arikunto descriptive research is not intended to test a particular hypothesis, but only describes what it is about the variable.

Unit of analysis in the influence of batik motif mega cloudy art Cirebon against fashion in Jakarta.

Research question

\begin{tabular}{|l|l|l|l|}
\hline \multicolumn{1}{|c|}{ Research question } & \multicolumn{1}{|c|}{ Aspects in question } & \multicolumn{1}{c|}{ Data Source } & \multicolumn{1}{c|}{$\begin{array}{c}\text { Data } \\
\text { Collection } \\
\text { Technique }\end{array}$} \\
\hline $\begin{array}{l}\text { 1 How fashion design } \\
\text { concepts collaborate with the } \\
\text { art of mega overcast motives } \\
\begin{array}{l}\text { a. Fashion design concept } \\
\text { b. Collaborative fashion } \\
\text { design with mega overcast } \\
\text { motif a. Lecturer or faculty } \\
\text { member }\end{array}\end{array}$ & $\begin{array}{l}\text { a. Fashion design concept } \\
\text { b.Fashion design } \\
\text { collaboration with mega } \\
\text { cloudy motif art } \\
\text { c. Student / student } \\
\text { d. General } \\
\text { Interview }\end{array}$ & $\begin{array}{l}\text { a. Lecturer or } \\
\text { faculty member } \\
\text { b. Student } \\
\text { c. } \\
\text { Administration } \\
\text { staff } \\
\text { d. General }\end{array}$ & interview \\
\hline $\begin{array}{l}\text { 2. What about the } \\
\text { development of fashion hijab } \\
\text { in Jakarta with mega cloudy } \\
\text { motifs in accordance with the } \\
\text { culture in Indonesia }\end{array}$ & $\begin{array}{l}\text { a. Fashion with the concept } \\
\text { of hijab collaboration art } \\
\text { batik mega cloudy motif, is } \\
\text { in accordance with the } \\
\text { culture of Indonesia }\end{array}$ & $\begin{array}{l}\text { a. Lecturer or } \\
\text { faculty member } \\
\text { b. Student } \\
\text { c. } \\
\text { Administration } \\
\text { staff }\end{array}$ & interview \\
\hline
\end{tabular}




\begin{tabular}{|c|c|c|c|}
\hline & & d. General & \\
\hline $\begin{array}{l}\text { 3. What about the price } \\
\text { standard with the art of batik } \\
\text { mega cloudy with the market } \\
\text { share of middle and upper? }\end{array}$ & $\begin{array}{l}\text { a. Prices that match the } \\
\text { market's ability to enhance } \\
\text { the creative industry }\end{array}$ & $\begin{array}{l}\text { a. Lecturer or } \\
\text { faculty member } \\
\text { b. Student } \\
\text { c. } \\
\text { Administration } \\
\text { staff } \\
\text { d. General }\end{array}$ & interview \\
\hline $\begin{array}{l}\text { 4. What about Patent Art } \\
\text { Mega Overcast motive? }\end{array}$ & $\begin{array}{l}\text { a. Patent art motif mega } \\
\text { overcast cirebon }\end{array}$ & $\begin{array}{l}\text { a. Lecturer or } \\
\text { faculty member } \\
\text { b. Student } \\
\text { c. } \\
\text { Administration } \\
\text { staff } \\
\text { d. General }\end{array}$ & interview \\
\hline $\begin{array}{l}\text { 5. How about fashion } \\
\text { promotion with mega cloudy } \\
\text { motive in order to improve the } \\
\text { development of creative } \\
\text { industry? }\end{array}$ & $\begin{array}{l}\text { a. How about fashion } \\
\text { promotion with mega } \\
\text { cloudy motive in order to } \\
\text { improve the development of } \\
\text { creative industry? }\end{array}$ & $\begin{array}{l}\text { a. Lecturer or } \\
\text { faculty member } \\
\text { b. Student } \\
\text { c. } \\
\text { Administration } \\
\text { staff } \\
\text { d. General }\end{array}$ & interview \\
\hline
\end{tabular}

The history of batik development in Cirebon is related to the development of the tarekat movement which is supposedly centered in Banjarmasin, South Kalimantan. Batik was originally done by members of tarekat who served in the palace as an economic source to finance the tarekat group. The followers of the tarekat live in the village of Trusmi and its surroundings. Another story tells that batik in Cirebon begins with the role of Ki Gede Trusmi, a loyal follower of Sunan Gunung Jati who teaches batik while spreading Islam.

Cirebon is one of the batik producing regions that have unique and distinctive motifs. Batik Cirebon belongs to the group of batik Pesisiran. But some batik Cirebon included in the group batik Keraton, namely Keraton Kasepuhan and Keraton Kanoman. Batik keraton including classic batik, for example motif Paksinaga Liman, Megamendung, Patran Keris, Lion Umbrella, Lion Barong, and so forth.

\section{Batik Cirebon}

Batik (or Batik word) comes from the Javanese language "amba" which means writing and "point". The word batik refers to the fabric with a pattern produced by the "night" material (wax) applied to the fabric, thus blocking the entry of dye, or in English "wax-resist dyeing".

Batik is a craft that has high artistic value and has been a part of Indonesian culture (especially Java) since a long time. Javanese women in the past made their skills in batik as a livelihood, so that in the past batik work was the exclusive work of women until the discovery of "Batik Cap" which enabled the entry of men into this field. There are some exceptions to this phenomenon, namely coastal batik that has a masculine line as can be seen in the "Mega Overcast" style, where 
in some coastal areas batik work is common for men. Traditional batik still retains its style, and is still used in traditional ceremonies, because usually each style has its own symbols.

Batik technique has been known since thousands of years ago. There is no clear historical information about the origin of batik. Some suspect this technique originated from the Sumerians, then developed in Java after being brought by Indian traders. Batik tradition at first is a tradition that hereditary, so sometimes a motif can be recognized from certain family batik. Some batik may indicate the status of a person. Even today, some traditional batik motifs are only used by the royal family. Batik Indonesia, as a whole of technology, technology, and related motive and cultural development, by UNESCO has been designated as Humanitarian Heritage for Oral and Nonbendawi Culture since October 2, 2009.

Batik technique is divided into two, namely: Batik tulis is a cloth decorated with texture and batik style using the hand. Making this type of batik takes approximately 2-3 months. Batik cap is a cloth decorated with texture and batik style formed with a stamp (usually made of copper). The process of making this type of batik takes about 2-3 days.

To more easily recognize Cirebon batik there are special features, ie there is a thin or small line in the term batik Cirebon called Wit. Wit is a contour line or water strap or also lung-lungan and the like, which is relatively small, thin and smooth which is older than the base color of the fabric.

The term Wit is only found in Batik Tembokan (Cirebon), Popokan (Java), which at this time can only be done by Cirebon batik craftsmen. Wit line is found in ancient batik (ancient), although the batik is not from Cirebon like Pekalongan, Java, Madura, Indramayu, Garut, Banyumas, Jogjakarta, Surakarta, Pacitan, Trenggalek, Tuban, Sumenep, Ponorogo, Tulungagung, Jambi, Bengkulu, Palembang, Bali, Ketapang, NTT, NTB, Irian Jaya. The difference is seen from the way or technique of batik.

The term babaran simply can be matched with the composition of color or color mix. In Batik Cirebon can be found some kind of babaran like: Batik (1) Babaran Biron is processed only one time porodan and release the wax from a cloth called Mateng Pisan. Ancient batik Mateng Pisan is a new half-finished there are only two colors of light blue and dark blue or black only, but some are designed to be ready to use with a blend of colors that are not bound according to his wishes. (2) Babar Mas is processed two times porodan with the following colors: thin base color while the color of the ornament or motif is dark blue, black and brown soga, some isen-isen type sesek (narrow) colored brown (on black ornament). (3) Babaran Bang Blue, Classified twice porodan, usually batik bang Biru this shows the basic color of white or beige, light brown (thin). While the motive is red, blue, and partly violet blackish. (4) Babaran Soloan, Batik basic color is old color is not bound, while the contour line and motif colored young. Babaran can be made one or two porodan.

(5) Babaran Sogan, Babaran is made with one time porodan while the color composition is free. But for isen-isen color must be brown soga except the isen in the form of these points should be white. (6) Babaran Tiga Negri, Tiga Negri is processed with three times porodan. The blend color is various, among others, red, blue, yellow, violet, and brown soga more dominant that is 
limited with certain lines. The main ornaments are red while the base cloth is given extra. (7) Babaran Meteron, This batik is made twice porodan with the main ornaments of flowers or buqet, the color red is the basic color of white cloth or other thin colors that are equipped with ornament lines or ukel-ukel the color is brown soga. (8) Babaran Tluki, this type uses flower motifs, leaves, small-shaped items with red and red-painted design combined with black, while the base color of cream or yellow thin. Batik Cirebon is a coastal batik, batik that is easily influenced by the variety of ornamental outside. The coastal area is located on the beach / harbor where a nation comes and stops there and then gives birth to an inter-nation cultural alcurturation. Cirebon coastal batik, much influenced Chinese culture, arabic and Indian culture, but the most prominent is the Chinese culture, the character is with bright colors and more contrast. Cirebon is unique in classical architecture, batik textiles, woodcarving, and inverted glass paintings. Cirebon music (among various streams) includes 2 kinds of Gamelan, Gamelan Prawa and Pelog Gamelan, plus three ancient ensembles of Gong Renteng, Denggung, and Gong Sekati. Cirebon is also known for its ancient traditions, mask dance, and two kinds of puppet theater, namely Wayang Kulit and Wayang

\section{Philosophy Batik of Megamendung}

Megamendung motif used by the people of Cirebon as the basic motive of batik is no stranger to the people of Indonesia lovers of batik, as well as for batik lovers in abroad. Evidence of Megamendung motif fame comes from the city of Cirebon once used as a cover of a book of batik published abroad entitled Batik Design by Pepin Van Roojen Dutch. History of the emergence of motives Megamendung adopted by the Cirebon community taken from various books and literature always leads to the history of the arrival of the Chinese who came to the region of Cirebon. It is recorded in history that Sunan Gunung Jati married Queen Ong Tien from China. Some of the art objects that were brought from China include ceramics, plates, fabrics that adorn the shape of clouds. The form of a variety of cultures represents the world over when taken from the ideology of Taoism. The shape of the cloud is a picture of the world wide, free and has a meaning transidental (Godhead). The concept of the cloud also influenced the Islamic world of the 16th century used by Sufis for the expression of the great world or the outdoors.

The basic values in Megamendung the basic values in any art including batik motifs megamendung art can be approached in the following way:

1) Value Appearance (appearance) or value of the form that gave birth to the art object. This value consists of the value of the shape and value of the structure. The visible value of the shape is visually motive megamendung in a beautiful fabric regardless of the use of materials in the form of cotton cloth or silk fabric. While in the value of the structure is produced from the forms arranged in such a way based on the essential value. The forms are curved lines arranged uniformly and unbroken to meet each other.

2) Content that can consist of the value of knowledge (cognition), the value of taste, intuition or the subconscious of human beings, the value of ideas, and the value of messages or values of life which can consist of morals, social values, religious values etc. In the form of Megamendung we can see regularly regular curved lines from the form of the most deep curved lines (smaller) then widen out (enlarge) shows a harmonious regular motion. It can be argued that this uniform curve brings a moral message in the ever-changing (up and down) life of human life and then develops out to seek identity 
(learn / live the social life of religion) and ultimately leads itself into a new world leading back into self-union after going through the tides (up and down) in the end back to its origin (sunnatullah). So we can see the form megamendung always formed from small arches that move enlarged continue out and in the end must return again into a small round but should not be interrupted.

Apart from the meaning of philosophy that Megamendung symbolizes human life as a whole so that its form must be united. Viewed from the side of production does require that the shape of the curved lines megamendung must meet at one point the next curve so that at the time of giving the gradual process of color (from the color of the young to the old color) can be more convenient.

When we look, then we will get that Megamendung form a lot of variations. There is a pointed shaped at the end and there is a dull round shape at the end. There is also a corner-shaped indentation in the shape of the curve. By itself for beginner batik designers who are not familiar with the process of batik and do not understand the meaning of philosophy Megamendung, when drawing Megamendung will be a little difficulty and possibly going wrong. To be noticed again is Megamendung motif almost similar to the motive Wadasan. But not the same placement with Wadasan motif (need to be studied specifically on the next occasion).

3) The value of Disclosure (presentation) that can indicate the value of a person's personal talent, value of skills, and the value of the medium he uses. The phrase presented by the artist in the form of a beautiful batik process by providing a scratch wax through a tool called canting made of thin copper material carefully formed so that the hot wax that passes through the canting end can flow smoothly. A harmonious blend of color elements with full meaning to whoever sees them. The element of the blue color that we know by symbolizing the color of the sky is so vast, friendly and quiet. Coupled with someone who interpreted that the blue symbolizes fertility so that the color of batik Megamendung at first always provide elements of blue color interspersed with red base color.

The development of batik world is growing with the demand for batik is so diverse, then the motives Megamendung much modified with various approaches, as follows:

1) Shape Motif Megamendung motif shape at the present time has changed a lot and modified in accordance with market demand by the community of fashion designers (fashion designer). It is undeniable that the group of fashion designers contributed enormously to the advancement of the world of batik including to lift motives Megamendung. Megamendung motif has been combined with the motifs of animal shapes, flowers or other motif elements. In fact the existence of Megamendung motifs combined with other motifs have existed since ancient times and have been made by traditional batik artists. But lately after being appointed in total by the fashion designer batik motif Megamendung growing rapidly.

2) Production Process The production process of batik Megamendung formerly done in batik tulis and batik cap, now also developed with the production process of screen printing (print). Thus the price of production can be reduced more cheaply. Although Megamendung-patterned fabrics made with silk-screening process can not be called batik, Megamendung's motive is a soft target for textile producers that can generate many benefits. 
3) Form of Production The present form of production objects that wear Megamendung motif is no longer in the form of batik cloth. Megamendung motif is used as a wall decoration of glass painting, on interior products such as wood carvings, adapula used as products pillowcases, bed sheets, tablecloths (household) and others.

I agree and strongly support the opinion of a group of batik lovers who make megamendung motif is a form of work that is very noble and full of meaning, so the use of megamendung motif should be well maintained and placed properly. We as a society engaged in the world of batik does not limit how the shape of megamendung motif is produced, but I do not agree when the motives megamendung with various forms used as production goods in the form of slipper coatings in hotels. Author: H. Komarudin Kudiya S.IP, M.Ds. Daily Chief of West Java Batik Foundation (YBJB).

Conversely, batik pesisiran develop quickly. Coastal communities become the main dispersing agents, they are much in touch with other nations, which then enriched the motifs and colors of batik pesisiran. Batik was no longer worn by the limited circles, even a commodity trading and livelihood for the people of Cirebon until now.

\section{Fashion}

Batik art is a traditional Javanese art that faces the threat of change in the era of globalization. Batik textile industry that was originally labor-based (labor intensive) turned into a capitalintensive mass industry (capital intensive). Especially in Jakarta as the capital and icon of Indonesia is the center of fashion throughout the region in Indonesia. Batik here is better known as the textile industry than a work of art, the process of manufacture is no longer using canting with individual hands but using textile printing machines, for mass production of mass production then made various needs clothing / apparel. But some designers homeland still many who use pure batik art / traditional batik mega cloudy. Batik mega cloudy initially only used by upper middle class who really understand the fashion, every fashion fashion designer fashion performances always promote batik megamendung as one of the alternative clothing ready to wear that is very charming and unique. In proclamir as fashion trends from 2007 to currently. Originally batik mega cloudy in the design for formal clothing and parties of the upper class, but over the times and fashion trends that increasingly rapidly growing fashion shirt model more and more from the formal penetrated into everyday clothes and accessories, for men and women aupun children, child. And no longer only in the upper middle class, but all circles are now wearing batik.

In addition batik art is relatively vulnerable to violations of intellectual property rights because of its nature as a traditional art that is less familiar with the concept of copyright. This situation not only threatens the cultural identity but also the Indonesian economy.

The presence of batik clothing design that has followed the development of fashion era is expected to strengthen the batik as textile and art native Indonesian culture. Buying and using batik is expected to maintain the preservation of batik techniques with canting continue to produce and absorb local workforce. 
Batik fashion art design in differentiation into two, namely: Classic batik has become a heritage has a high value and taste of art, with elaborate workmanship and within weeks. Classical batik has certain basic patterns with various variations of motifs, such as kawung, machetes, nitik, tuntum, ceplok, tambal, and so forth. Batik basic materials in the form of fine white cotton fabric, also white silk cloth, batik with silk material will produce a more vibrant color. Unlike the classic batik, in modern batik motif and coloring does not depend on the patterns and coloring as certain in classic batik, but the dress design can be anything and colors of various kinds. Modern batik also uses materials and coloring processes that follow the development of the coloring materials. Sometimes in some areas of t-shirt design, canting is not used but using brushes and for staining is sometimes applied directly by using cotton or cloth. In other words, the process of making modern batik is almost like a classic batik but the design of modern batik shirt and coloring of modern batik clothes is up to the taste of t-shirt design and depends on the ingredients of the colouring. Even with the growing base of fabric and colored fabrics, modern batik becomes more varied, such as batik on cotton lurik Jogja, poplin fabric, pajama material, wool material, etc.

Mega cloudy batik fashion art is considered promising by some designers of Indonesia, because diangap can help the people's economy, demand more and more, so as to open new jobs for those in need.

\section{The development of fashion batik motifs in Jakarta and the World}

The most famous motif and become the icon of Cirebon is the megamendung motif, which is included in this type of wadasan. This motif has a very good gradation color, ordinary coloring done more than three times. Batik motif megamendung symbolizes the rain cloud carrier as a symbol of fertility and giver of life. The history of this motif relates to the history of the arrival of the Chinese in Cirebon. Sunan Gunung Jati who developed Islamic teachings in the area of Cirebon married a Chinese princess named Ong Tie. This Cloud motif illustrates the influence of Chinese culture in Cirebon batik design. Inspired by art objects brought from China such as ceramics, plates and cloth decorated with clouds. The palace batik pours Chinese culture and traditions into the batik motifs they make, but with a distinctive touch of Cirebon. There is a difference between the megamendung motif of China and the one from Cirebon, on the motif of the Chinese megamendung, the spherical or circular cloud line, while the Cirebon, the cloud line tends to be oblong, pointed and triangular.

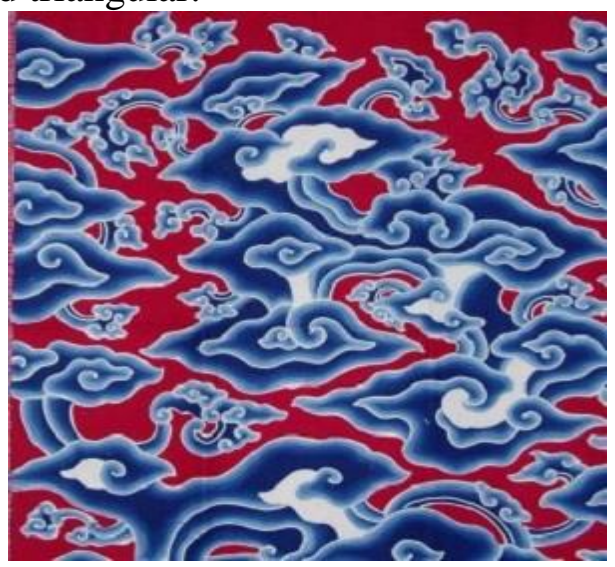

Picture 4.1: Batik Cirebon Motif Megamendung

Reference: http://budaya-indonesia.org 
Characteristic and uniqueness of Batik Cirebon are:

1) Cirebon Batik is a classic nuance usually always include wadasan motif (rocks) or megamendung on certain parts of the motif.

2) Classic Cirebon Batik has a background color that is younger than the line color on its main motif.

3) The background or base of the fabric usually appears to be clean of black spots or unwanted colors in the manufacturing process.

4) The motif lines of Cirebonan batik use single and thin lines (small) of approximately 0.5 $\mathrm{mm}$ with the color of the lines older than the background color. This is because the process of batik Cirebon superior in the closure by using a special canting to make the process of closing, that is by using canting wall and bleber

5) The dominant colors of traditional classical Cirebon batik usually have a yellow color (rubbing sogan), black and cream base color, or dark red, dark blue, black with a cream or ivory white base color.

6) Batik Cirebon tend to choose a part of the fabric background is left empty without filled with decorations in the form of tanahan or rentesan.

7) Batik Cirebon dare to use bright colors such as red, blue, green, yellow, purple, pink even white base color is often used.

8) Has a style that is influenced by the culture of foreign nations that once had close relations with Cirebon such as Europe, Gujarat, China, India, and others.

9) The depiction of a natural and what is in the style of Batik Cirebon make Batik Cirebon easy to apply to modern fashion trends.

\section{Influence of Art Batik motif Megamendung Cirebon to fashion in Jakarta}

Fashion Megamendung by Menul and Melisha with the theme "megamendung" to use batik motif Mega Mendung typical Cirebon which is identical with a large collection of clouds. The design is to describe the figure of cosmopolitan and modern women so that the culture of Indonesia is not shown heavy and serious, but lighter and more colorful. Creativity does not mean to be a unique or strange dress. But how to process batik decoration is very modern without damaging the batik motif itself. So produced a ready-to-wear clothing collection that is light and casual with the breath of the trend culture in Jakarta by using Hijab.

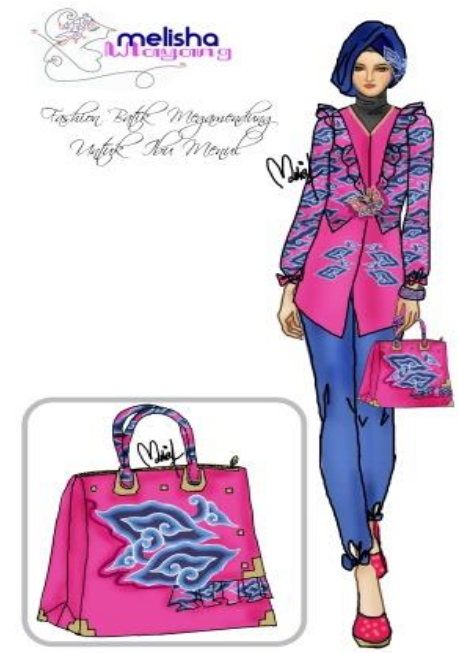

Picture 4.2: Design by Melisha Rousellyn with Menul Teguh Riyanti 
The concept of a fashion design plan to be created by researchers and collaborating with melisha as a partner in research using hijab modern impression but still look Indonesian culture become icon. As well as bright colors look very interesting mega cloudy theme.

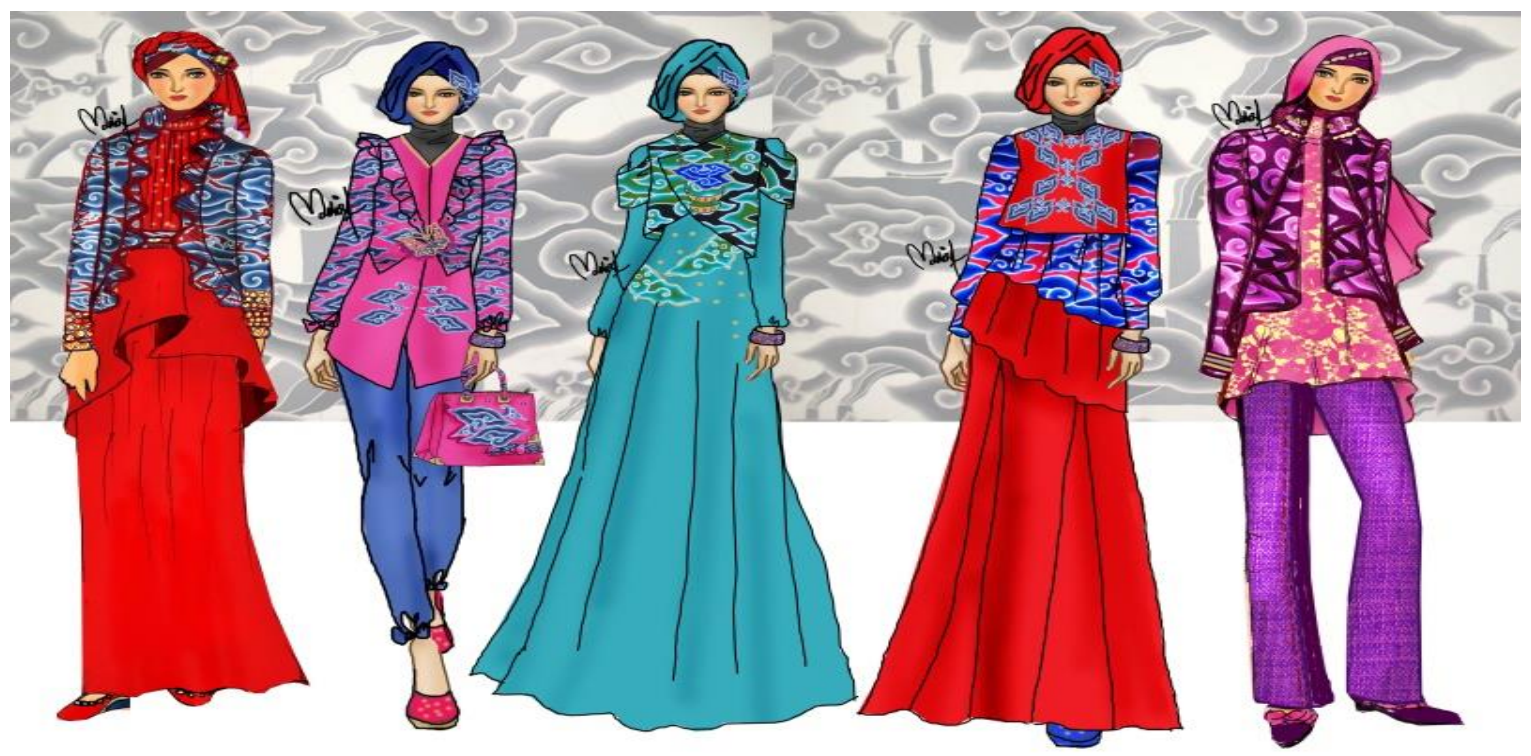

Picture 4.3: Design by Melisha Rousellyn witt Menul Teguh Riyanti

The concept of fashion design is to increase the selling and competitiveness of international and national level. The design collaborated with the talented young designer with researchers. The final draft is agreed with selected mega cloudy motive art as an icon or image that has been famous in the world as a world heritage. The design was agreed on June 24, 2015 by the young Designer and Researcher. For Design we create some fashion designs can be used among young and Adult. In the design concept we need to know how to market a good and fast product as a medium of advertising communication and can increase competitiveness in the country and international level.

\section{Quesioner}

ASPECT DESIGN, ESTETICS, PRICE (50 people)

\begin{tabular}{|l|l|c|c|c|c|}
\hline No. & Statement & VA & A & NA & NVA \\
\hline 1 & $\begin{array}{l}\text { Do you think the five hijab fashion concepts with a mix of mega } \\
\text { cloudy batik motifs are very interesting? }\end{array}$ & 10 & 40 & & \\
\hline 2 & $\begin{array}{l}\text { Do you think the five hijab fashion concepts with a mix of batik } \\
\text { mega cloudy batik can be worn by all walks of life and age? }\end{array}$ & 50 & & \\
\hline 3 & $\begin{array}{l}\text { Are the five concepts of batik mega cloudy batik already in } \\
\text { accordance with Indonesian culture? }\end{array}$ & 50 & & \\
\hline 4 & $\begin{array}{l}\text { Is the blend of color with batik mega cloudy motif is appropriate } \\
\text { according to you? }\end{array}$ & 50 & & \\
\hline 5 & $\begin{array}{l}\text { According to you for the use of batik motifs mega overcast using } \\
\text { writing techniques to adjust the ability of the community? }\end{array}$ & 50 & & \\
\hline 6 & $\begin{array}{l}\text { Do you think the price matches the ability of the upper middle class } \\
\text { from Rp } 1,000,000,- \text { up to Rp } 1,500,000,- \text { for a set of clothes? }\end{array}$ & 10 & 10 & 30 & \\
\hline
\end{tabular}




\begin{tabular}{|l|l|l|l|l|l|}
\hline 7 & Mega cloudy batik motif made into fashion products & 50 & & & \\
\hline 8 & $\begin{array}{l}\text { Fashion mega cloudy motives do you think is as good as marketed } \\
\text { through social media inform to the international arena? }\end{array}$ & 50 & & & \\
\hline 9 & Do you think the patented mega patent pattern should be? & 50 & & & \\
\hline 10 & $\begin{array}{l}\text { Is mega mendung motif may be developed according to the times and } \\
\text { remain in accordance with the standard }\end{array}$ & 40 & 8 & 3 \\
\hline
\end{tabular}

The design model of hijab clothes with colaboration mega mendung

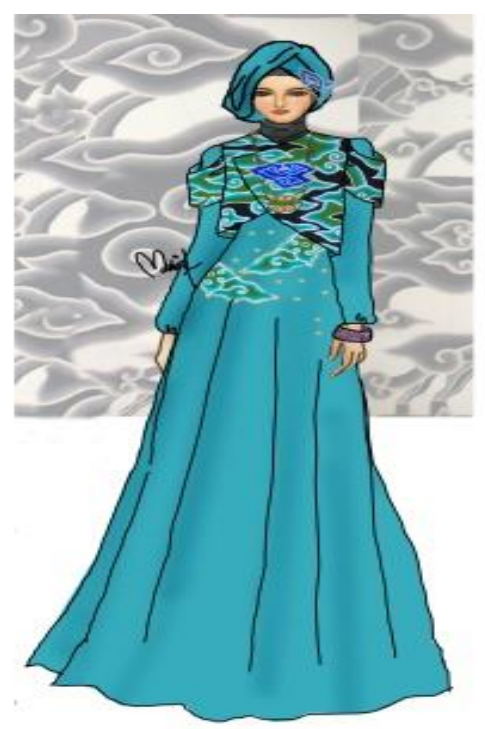

Design favorite

Picture 4.4: Design by Melisha Rousellyn witt Menul Teguh Riyanti

Analyze the design model of hijab clothes with colaboration mega mendung motif as well as selected and favorite can be seen from the questioner that circulated to lecturers, general and students, especially in Jakarta as the center of fashion or trend of hijab clothes as world trend later.

That clothing other than to cover the body or aurat as well as beauty by the wearer. In the book The Second Skin, mentioned the purpose of fashion in terms of various points of view as follows; 1. From the study of Anthropology; Anthropological studies enable us to conclude, for example, that using clothing to express modesty is a function that is determined by the culture, by instinctive in nature. People cover or decorate their bodies for, variety of reasons and modesty is only one. Other reasons include protection, the desire to be sexually attractive, and adornment. (Hom \& Gurel 1981: 3)

Anthropological studies have led to the conclusion that humans or a particular group of people dressed in the purpose of covering the body is a function determined by the culture one learns and not merely natural instincts. Another reason is to protect the body, adorn the body and the desire to appear sexually attractive. In addition to attractive design and very simple and flexible use in the event office or banquet. 
Harmony between placement motif, model and color design of hijab clothes is to use aesthetics for how to combine the motif with the color. The aesthetic word comes from the Greek word 'Aisthesisis' which carries the meaning of sensitivity. This term gives support only to the things concerned with the beautiful expression and beauty. Aesthetic theories pile up to the things that concern the sense of beauty in a result of the art of human creation as a work. Aesthetics is a study of the beauty (Science of beauty) is about perception or observation about the field of art. The term aesthetic was introduced by Alexander Baumgarten (1742-1762) a German philosopher. The philosopher George Whilhem Fredrich Hegel (1770-1831) thinks that aesthetics is part of a broad field of philosophy. The aesthetic concept is a concept of being as a result rather than a wonderful conversation about the theory of beauty and art theory that is the twin headline in the history of human thought. According to Sri Widarwati (1993), the aspects of the principles in harmony or harmony are as follows:

1) Alignment in lines and shapes

2) Alignment in texture

3) Alignment in color

\section{Proportion}

The proportions are relationships with each other in a single arrangement (Widjiningsih, 1982: 13). Comparison is used to reveal more. In Fashion and Identity the work of Fashion theory from Fred Davis (1992) says that there is a significant relationship between fashion, culture, and identity (Dewi Meyrasyawati, 2013: 101) According to Dewi Meyrasyawati Fashion and Identity (2013: 101) he quotes " we see fashion as a cultural phenomenon, then the clothing was none other than a meaningful practice that took place in everyday life, which helped shape the culture as a system of general meaning. Therefore, clothing is one place for human to communicate, experience, explore, and produce social order "(Barthes, 1983: 3-5). In this discussion about fashion design, can be seen how fashion system construct cultural values. Cultural studies see the phenomenon of fashion as something that is constructed by the fashion system. Adolescents identify the culture they profess through how they dress. Referring to the theory of fashion system from Roland Barthes (1990), fashion is a sign system. The way we dress is a sign to show who we are and what our cultural values are. So the way of dressing is no longer seen as something neutral and something commonplace. Big or smaller and gives the impression of a relationship with each other that is clothing with the wearer (Sri Widarwati, 1993: 17). Proportion is the principle of the relationship between the design department as a whole (Sri Ardiati Kamil, 1986: 62). The proportion is the ratio of the parts to the other parts that are combined (Ernawati, 2008: 211)

Toffler's lifestyle means that every individual has a mark as his identity to distinguish it from other groups (Walker, 1989: 155). The lifestyle of a person or group of people, one of which relates to the way a person conducts his life, how one decides to choose and make choices. Toffler's argument is reinforced by Chaney's assumption that lifestyle is a picture of modern life or so-called modernity, meaning that those who live in modern society will use lifestyle devices to identify their actions as well as others.

Lifestyle is the pattern of action that distinguishes a group of people with other groups (Chaney, 1996: 4). Lifestyle is a part of everyday human life, and its function is to interact in various ways, where aka tone is likely to be unintelligible or unacceptable to those who live in a modern 
society. According to Chaney, the polapola of social life is sometimes characterized by the existence of culture. Some observers define culture as the totality of the lifestyles of a society that includes traditions, attitudes and norms that unite them into a society.

As for his relationship with fashion or fashion, Walker in his book Design History of Design on styling and lifestyle styles, style and fashion, mentioned that fashion can refer to a variety of human attitudes, but more precisely refers to the enthusiasm of a person in certain fashion a fashion (style) and fashion are closely related to one's appearance or attitude, which of course must involve the factors of consumption, reception and taste (Walker1987: 171). According to Russell, 1992:55), one of the most versatile elements for a design is color. Color can attract attention and help create a mood (mood). Depending on the appeal of a design work, colors can be used for the following reasons:

1) Color is a tool to get attention

2) Colors can highlight realistic elements realistically in color

3) Color has a psychological language that composes the work Design according to Reswick is "creative activity that brings renewal". In addition to the design also contained several things, among others: taste, creativity, taste, self-esteem, privacy, values, norms of pride, private happy and so forth, all of which can not be measured mathematically. In the design itself required a concept known as the design concept, which includes design philosophy and considerations aimed at realizing the idea / design that is reality. This is called the conceptual design, namely:

1) Functions; functional meaning appropriate, functional design means appropriate design

2) Safe; safe means to protect people from harm, meaning that the design must be precisely to make quiet for the connoisseur of the design itself, janan up because the design makes it restless and uneasy

3) Skilled; skilled means deft, agile, nimble, capable, and ingenious. In the world of skilled design are often also understood understanding of mastery of engineering

4) Economical; the design requirements, especially those that are related to production are the economic considerations. Economics does not necessarily relate to price, but also information about efficient, effectiveness, and practical form of the end of a design.

5) Aesthetically; aesthetic is a personal medium that includes: character, character, attitude, belief, mood, depth, maturity personality. In the design work, aesthetic aspects are very necessary to note for the right form and harmonious

6) Attitude (ethical dimension); attitude is part of the depth of a work. A design that does not have the same attitude as a man hesitates.

\section{Conclusion}

Batik is a craft that has high artistic value and has been a part of Indonesian culture (especially Java) since a long time. Batik Cirebon is a coastal batik, batik that is easily influenced by the variety of ornamental outside. The coastal area is located on the beach / harbor where a nation comes and stops there and then gives birth to an inter-nation cultural alcurturation. Today's fashion art, applying a lot of batik in everyday fashion, formal or informal because batik is considered attractive, distinctive and has a high value sense artistic image. The presence of batik clothing design that has followed the development of the era is expected to strengthen the batik as a textile and art native Indonesian culture. 
The users of batik mega cloudy is expected to grow a sense of love for the batik, so they want to use, and proud of the batik and want to use it for everyday fashion both formal and informal. Batik art is actually full of ethical and aesthetic education for women of old. Batik is a trace of history that marks an important event in the life of Javanese society from the past until now. So no wonder, batik always experience development and berakulturasi with the culture around him. The development indicates the location, place, and the soul of each art of batik craftsmen from generation to generation.

\section{Suggestion}

Batik motif mega cloudy needs to be preserved and should be patented for the motive as a heritage of the Indonesian nation and especially the area of Cirebon.

Makes mega cloudy motif is a form of work that is very sublime and full of meaning, so the use of mega cloudy motif should be well maintained and placed properly. We as a society engaged in the world of batik does not limit how the shape of motifs produced megamendung, megamendung motifs with various shapes placed as the main accessories.

To preserve the megamendung motif should be from elementary school to college level given training on how to make batik regeneration does not die.

The more rich the batik motif in Indonesia. Love the culture of Nusantara, proudly wearing batik on various occasions. Because batik is a nation's cultural heritage that must be preserved. Moreover, batik motifs save a lot of historical stories of the past and the philosophy of life adopted by the ancestors.

Megamendung motif is a form of work that is very sublime and full of meaning, so the use of megamendung motif should be well maintained and placed properly. This statement does not intend to limit how the megamendung motif is produced, but rather the disagreement of using megamendung motifs for items that are otherwise inappropriate, such as sandal coatings in hotels.

\section{References}

[1] Birrren, Faber. 1976. Colour Perception in Art. Van Nostrand Reinhold Company Division of Litton Educational Publishing, Inc.

[2] Darmaprawira W.A, Sulasmi. 2002. Warna, Teori dan Kreatifitas Penggunaannya. Bandung: ITB.

[3] Doellah, H. Santosa, 2002, Batik: The Impact of Time and Environment, Surakarta: Danar Hadi.

[4] Hasanudin. 2001. Batik Pesisiran. Bandung: PT Kiblat

[5] Roojen, Pepin Van. "Batik Design". Amsterdam dan Kuala Lumpur: The Pepin. Press, 1996.

[6] H. Komarudin Kudiya S.IP, M.Ds "Motif Batik Megamendung, nilai seni dan filosofinya".Netsains. 17 Februari 2009.

*Corresponding author.

E-mail address: menulsukarno@ yahoo.com 